\title{
日本動物心理学会第78回大会
}

(平成30年 8 月 28 日 30日)

日本動物心理学会第78回大会（JSAP2018）が，広島大学の坂田省吾を大会委員長，有賀敦紀准教授（広 島大学) を事務局長, 牛谷智一准教授 (千葉大学), 後藤和宏准教授 (東海女子大学), 澤幸祐教授 (専修大 学), 友永雅己教授 (京都大学), 菊水健史教授 (麻布大学), 佐藤暢哉教授 (関西学院大学), 井上紗奈准教 授 (甲南女子大学), 菱村豊教授 (広島国際大学), 中嶋智史講師 (広島修道大学), 小野田慶一講師 (島根 大学), 服部稔助教 (広島大学), 崪本裕也助教 (山口大学), 中村勇太大学院生 (広島大学), 曲若衡大学院 生 (広島大学), 任旭縁大学院生 (広島大学) を準備委員として, 平成30年 8 月 28日〜30日の 3 日間にわたり 東広島市で開催されました。広島大学が日本動物心理学会大会を主催するのは長い歴史の中で初めてです。 会場はJR 山陽線の西条駅に近い東広島芸術文化ホール「くらら」でした。

7 月 6 日に発生した豪雨災害により，JR 山陽線は不通になり，新幹線の東広島駅から JR 西条駅までバ スによる代行輸送で会場まで来ていただきました。会場は2016年春にオープンした新しい施設で幸い豪雨災 害の被害はありませんでした。災害でお亡くなりになられた方々のご冥福をお祈りするとともに被災されま した多数の方々にこの場を借りてお見舞い申し上げます。会場変更も検討されましたが，復興支援の意味を 込めてそのまま東広島市西条で開催することになりました。

大会初日 8 月28日（火）の午後から「補助犬の普及について考える一市民と共に考える一」と題した公開 シンポジウムが開催されました。シンポジウムでは補助犬法「生みの親」で日本介助犬協会の高柳友子さん と創立50周年を迎えた日本盲導犬協会の訓練士を統括する訓練士でもある多和田悟さん，災害救助犬の訓練 とセラピードックにも関係されている日本レスキュー協会の伊藤裕成さん，それにアカデミックな立場から 麻薬探知犬の遺伝子を研究されている帝京科学大学の今野晃嗣さんに登壇していただき, それぞれのイヌと の関わりの中から訓練を通したヒトとイヌの関係を発表していただきました。高柳さんの発表では介助犬 PR 犬の「キャロル」が介助犬とはどのようなことをするのかを壇上でデモンストレーションしてくれました。 また，盲導犬訓練についても川本訓練士と山田訓練士がそれぞれ訓練犬を連れて登壇し，多和田さんの指示 の下に犬の訓練の様子を見せて下さいました。犬の擬人化への䀣念についても貴重な話を聞くことができま した。訓練法の背景となる理論に詳しい関西学院大学の中島定彦教授から最近の犬研究増加の指摘と, コメ ンテーターとして各発表者に対しての質問がなされました。全体の司会進行は，ヒトとイヌの関係に詳しい 麻布大学の菊水健史教授により進められました。

会場には盲導犬を連れた視覚障害者も参加され，補助犬や犬に興味ある市民も多数参加しました。初日の 公開シンポジウムには一般の参加者 97 名が参加し, 発表者や関係者を含めると 120 名を超える人達が内容の 濃い発表を聴くことができました。公開シンポジウムの終了予定時刻は午後 3 時30分でしたが，実際に終了 したのは午後 4 時でした。なお，本公開シンポジウムは日本学術振興会科学研究費補助金（研究成果公開発 表 (B)18HP0007) の助成を受けて行われました。

午後 4 時30分からは自由集会「動物による音響信号の利用とその進化」が関義正准教授（愛知大学）の企 画の下で開催され, 石川由希講師 (名古屋大学大学院理学研究科), 森千紘特別研究員 (東京大学大学院総 合文化研究科・日本学術振興会), 服部裕子助教（京都大学霊長類研究所）の 3 名が発表を行いました。自 由集会への参加者は67名でした。

公開シンポジウムとそれに続く自由集会は日本語での発表でしたが，2 日目，3日目の口頭発表およびポ スター発表はすべて英語で行われました。英語での発表形式は昨年の合同大会を除いて第74回大会から受け つがれています。英語発表が普通に行われるようになり，発表のレベルや質問への受け答えが上手くなって きたように感じられました。

口頭発表は26件あり，そのうち奨励賞対象発表は10件でした。ポスター発表は78件あり，そのうち学部生 発表が 8 件ありました。大会参加者数は170名（一般95名, 大学院生61名, 学部生14名）でした。多数の発 表をありがとうございました。

大会 2 日目は口頭発表 $\mathrm{A}$ (奨励賞選考対象発表) とポスター発表 $\mathrm{A}$ および口頭発表 Bがあり, 夕方から国際 
シンポジウム「Animal Cognition: Space, Timing, and Memory from Neuron to Behavior」が開催さ れました。講演者は Neuroplasticity, Exercise and Memory と題して発表した Duke 大学の Christina L. Williams 教授, Neural Basis of Memory in the Avian Forebrain と題して発表された Otago 大学の Mike Colombo 教授, 3 人目は Interval Timing Mechanisms in Support of Learning and Memory と題して発表した Duke 大学の Warren H. Meck 教授でした。120名の会員が参加しました。多くの質問 が出てたいへん白熱した議論が展開されたところで時間が来てしまい，続きはその後の貏親会へと引き継が れました。

大会 2 日目の夜に小ホールの隣にある「ソラオト」で103名が参加した懇親会が開催されました。国際シ ンポジウム参加者を中心に懇親会を目指して駆けつけてくれた参加者もいて，たいいん盛況でした。懇親会 では酒都西条で醸造されている美味しい日本酒が並心゙られ，皆さんに味わっていただきました。懇親会場が L字型だったので端と端の会話が難しかったかもしれませんが，一面がす心゙てガラス空でしたので 2 階から 眺める西条の夜景を楽しんでいただけたと思います。

最終日の大会 3 日目は午前中が口頭発表 C, 午後にポスター発表 Bが開催されました。参加者は114名で した。ポスター発表に続いて総会が設定されていましたので, ポスター発表の白熱した議論が途中で打ち切 られ残念な思いをした発表者もいたかもしれません。もう少し余裕のある時間設定ができればよかったので すが，その点は反省点です。申し訳ございません。一方ですべてが全会員に参加していただけるように組ん でいましたので，その点は多くの参加者から好意的な評価をいただきました。一本のタイムラインで進める 形式は今後も同様にしていただけるとよいかと感じました。

今回の第78回大会は多くの若手の会員に助けていただきました。実行委員会委員に入っていただいた先生 方には特に感謝申し上げます。皆様方の献身的なご協力がなければ決して開催できませんでした。何よりも 参加して下さった会員の方々，豪雨災害により交通が不便な中，何とかやりくりをして遠路西条までお出で いただき，復興にご協力いただいたことに感謝申し上げます。

文責 坂田 省吾 (広島大学)

\title{
日本動物心理学会第78回大会 公開シンポジウム
}

「補助犬の普及について考える一市民と共に考える一」

\author{
企画：坂田 省吾 (広島大学大学院総合科学研究科) \\ 司会：菊水 健史 (麻布大学動物応用科学科) \\ 話題提供：高柳 友子（社会福祉法人 日本介助犬協会） \\ 多和田 悟 (公益財団法人 日本盲導犬協会) \\ 伊藤 裕成（認定 NPO 法人 日本レスキュー協会） \\ 今野晃嗣（帝京科学大学生命環境学部アニマルサイエンス学科）
}

指定討論：中島 定彦（関西学院大学文学部総合心理学科)

\section{International Symposium}

Animal Cognition: Space, Timing, and Memory from Neuron to Behavior

Organize: Shogo Sakata (Hiroshima University) \& Kosuke Sawa (Senshu University)

Christina L. Williams (Duke University, USA)

Neuroplasticity, Exercise and Memory

Mike Colombo (University of Otago, New Zealand)

Neural Basis of Memory in the Avian Forebrain

Warren H. Meck (Duke University, USA)

Interval Timing Mechanisms in Support of Learning and Memory 
8月30日の最終日15時から小ホールで総会が開催されました。参加者は34名であった。各種議案の審議な らびに報告が行われた。

(1) 友永理事長より，第77回大会の実施や『動物心理学研究』発刊を含む平成28年度事業の報告があった。

（2）中島常任理事より，平成29年度決算報告があり，承認された。会計監査の結果の提示があった。

(3) 友永理事長より，平成30年度事業案が提示され，承認された。平成30年度事業の一つとして，今回大会 の概要について報告があった。

(4) 中島常任理事より，平成30年度予算案が提示され，承認された。

(5) 友永理事長より，平成31年度の大会を専修大学で開催する旨報告があった。準備委員会委員長に就任予 定の澤理事から大会の日程候補や概要について説明があった。

(6) 名誉会員として渡邊正孝先生（東京都医学総合研究所・特任研究員）・渡辺茂先生（慶應義塾大学・名 誉教授）の推薦があり，承認された。両氏のこれまでの貢献をたたえ，名誉会員証書の授与があった。

（7）報告事項として，ｉ）菊水常任理事より「動物心理学研究」編集状況及び特集号企画の報告があり，そ の後, 優秀論文賞 (第65巻 1 号 p.45-58 中尾央先生, 後藤和宏先生による「メ夕認知研究の方法論的課題」) の報告および授賞式が行われた。ii）友永理事長より 7 月 24 日に発生したメール配信システムによる，会 員メールアドレス情報の誤配信インシデントについて報告があった。

総会に続けて発表奨励賞受賞者の発表（最優秀賞 2 名，優秀賞 1 名）と表彰式が行われた。下記の 3 演題 が受賞した。

最優秀奨励賞 :

Neural basis for sensorimotor learning of pecking movement with an experimentally extended bill in pigeons.

松井大（慶応義塾大学大学院社会学研究科）

Pigeons do not see 2D visual motion from barber-pole and plaid stimuli.

幡地 祐哉 (京都大学大学院文学研究科)

優秀奨励賞 :

Chimpanzees, but not bonobos, preferentially view infants of own species over adults. 川口ゆり（京都大学霊長類研究所）

\section{講評 :}

今回の奨励賞発表には10名のエントリーがあり，口頭発表の Aセッションで英語でのプレゼンテーション が行われました。審査の結果, 平均得点は 18.4 となりました (25点満点)。今大会の最優秀発表奨励賞は 2 名で, 松井大さん（慶應義塾大学大学院社会学研究科）と幡地祐哉さん（京都大学大学院文学研究科）が受 賞されました。優秀発表奨励賞は川口ゆりさん（京都大学霊長類研究所）が受賞されました。受賞された皆 様，誠におめでとうございます。

最優秀発表奨励賞を 2 名に授与したのは，第76回大会に続いて 2 例目となります。上位 2 名の発表に対す る審査員の先生方の評価の点数が極めて高く拮抗し, 甲乙つけがたいほど 2 名の発表がともに優れていたこ とから，発表奨励賞選考委員会・理事会での審議を通して最優秀発表奨励賞を 2 名に授与することに決定い たしました。特に高く評価されたのは，丁寧に紡がれた研究背景から問題提起・目的への流れ，方法の妥当 性, 議論の論理性, 質疑応答を含む口頭発表技術でした。発表奨励賞は, 日々研究に勤しんでいる若手研究 者への集美であり激励の意味合いの強い賞ですので，お認めいただければ幸いに存じます。

さて，今年も例年通りのハイレベルな争いになりました。英語でのプレゼンテーションを入念に準備され ており，スライドも口頭での説明もよく整理されていたと思います。英語の発音の良さや，聴衆を見渡して 話す余裕も含めた発表スタイルにも，その準備の成果が反映されていました。英語でのプレゼンテーション スキルは年々着実に上がってきていると思います。

一方で, 例年話題にのぼることですが, 奨励賞対象の発表が英語での口頭発表になって以降, 奨励賞に応 
募する学生さんの数が減ったこと, 応募する学生さんの専門分野・所属に大きな偏りが見られるようになっ てきていることは残念に思います。受賞できれば，もちろん大きな励み・襄美になりますが，惜しくも受賞 を逃したとしても，希望者には審査員の先生方による評価・コメントが開示されることになっています。つ まり，奨励賞に応募することは幅広い専門分野の先生方から忌憚ない意見を多角的にいただける大変貴重な 機会につながり，自身の研究や発表に何が不足しているのか，どうすれば改善できるのか，を積極的に学ん でいただく良いきっかけになります。ぜひ幅広い分野・所属の皆様にご応募いただき，ご自身の研究内容を 充実させ，活躍の場を海外へと広げていくステップアップの場として活用いただきたいと思います。

ご多忙の中, 審査・選考を引き受けてくださった先生方, 坂田先生をはじめとする広島大学の皆様, 大会 の準備委員会の皆様に心より御礼申し上げます。

奨励賞選考委員会 瀧本 彩加 (北海道大学大学院文学研究科)

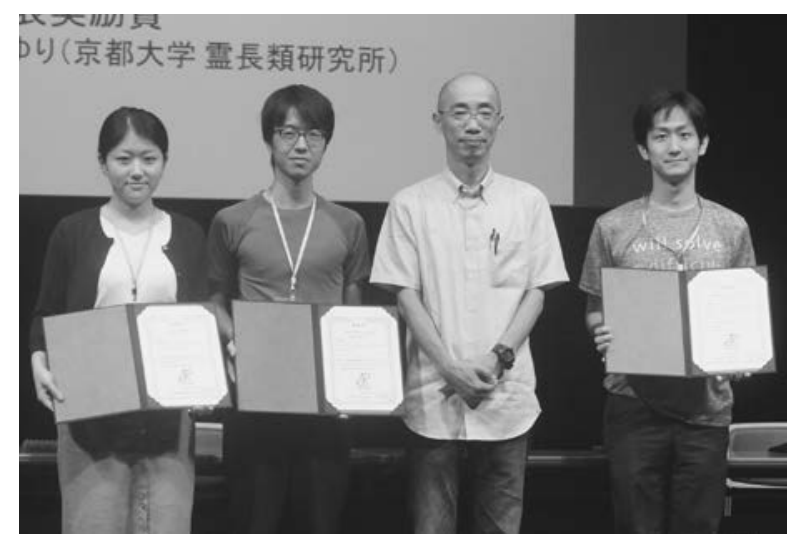

表 彰式にて

（左から川口ゆり氏, 幡地祐哉氏, 友永雅己理事長, 松井大氏) 


\section{収入}

前年度繰越金

5, 834, 739

年会費

賛助会費

会誌売上

寄付

大会校寄付

著作権料

広告料

受取利息
2, 011,500

10, 000

98, 000

15,743

500, 000

36,513

120,000

\begin{tabular}{ll}
\hline 計 $2,791,757$
\end{tabular}

\section{収支差額}

\section{平成30年度予算}

\section{収入}

$\begin{array}{lr}\text { 前年度繰越金 } & 6,066,887 \\ \text { 年会費 } & 2,180,000 \\ \text { 賛助会費 } & 10,000 \\ \text { 会誌売上 } & 120,000 \\ \text { 著作権料 } & 15,000 \\ \text { 広告料 } & 80,000 \\ \text { 雑収入 } & 5,000\end{array}$

計

8, 476, 887

\section{支出}

\begin{tabular}{lr} 
会費製作費 & 464,508 \\
第77回大会補助費 & 600,000 \\
例会補助費 & 50,000 \\
事務委託費 & 475,200 \\
事務用品費 & 73,970 \\
通信費 & 125,743 \\
旅行交通費 & 179,698 \\
大会・理事会費用 & 67,040 \\
理事会選挙費 & 432,833 \\
諸会費(心理学諸学会連合会費) & 15,000 \\
奨励賞賞金 & 25,000 \\
寄付・寄贈 & 40,954 \\
杂隹費 & 9,663 \\
\hline 計 & $2,559,609$
\end{tabular}

30 年度(第78期)への繰越額 $\quad 6,066,887$

（単位：円）

\section{支出}

\begin{tabular}{lr} 
会費製作費 & $1,000,000$ \\
第78回大会補助費 & 250,000 \\
例会補助費 & 150,000 \\
事務委託費 & 643,800 \\
事務用品費 & 120,000 \\
通信費 & 150,000 \\
旅行交通費 & 100,000 \\
大会・理事会費用 & 92,000 \\
諸会費(心理学諸学会連合会費) & 15,000 \\
編集部予算 & 40,000 \\
奨励賞賞金 & 35,000 \\
企画費 & $1,380,985$ \\
雑費 & 15,000 \\
予備費 & $4,485,102$ \\
\hline 計 & $8,476,887$
\end{tabular}




\section{動物心理学研究編集状況}

動物心理学研究第68巻 2 号をお届けいたします。本号では, 動物心理学会の大会の講演論文 2 本と, 意見 論文 1 本，また広島大学で開催されました動物心理学会第78回大会の要旨を掲載しています。

今年度の学会は, 皆様のご記憶にも残っていると思いますが， 7 月に西日本を襲った集中豪雨，特に被害 の大きかった広島での開催となりました。災害発生により多くの方々がお亡くなりになり，またいまだに復 旧も続く状態と伺っています。改めて，亡くなられた方々のご冥福をお祈りいたしますとともに，1日も早 い復旧を願います。そのような中，災害発生から１か月少しののちに学会が無事に開催されました。大会初 日に開催された，公開シンポジウム「補助犬の普及について考える一市民と共に考える一」も，平日開催で したが，多くの市民の方々のご参加を得ることができました。大会長の坂田省吾先生には気苦労が多くあっ たかと思いますが，大会開催にご尽力いただきました。誠にありがとうございました。

学会に参加し, 感じたことがありました。これまで学会の英語化を進めてきておりますが, 発表や質疑応 答を含め, 以前と比較して格段に良くなってきていると思います。他の学会でも, 学会の国際化が進んでい ますが，同じように，当初心配していたような状況は数年でリカバリーされ，学会らしい討論も見受けられ るようになりました。特に若い学生さんたちの吸収力はすごいな, と感心しています。今回の学会要旨も同 じように英文のみになっておりますが，そのような国際化の中での要旨掲載であることを，ご理解いただけ ればと思っております。

学会中に開催された動物心理学研究の編集委員会で, 正式に特集号の構成が決まりました。今回, 2 部構 成の出版を企画しました。一つは動物のもつ社会性について, もら一つは感覚運動機能をテーマにしました。 特に, 学部生など動物心理学研究の入り口にいる方に役立つような企画としています。今回は最初の試みの ため，編集部での企画としましたが，今後は会員からの企画の募集も考えていきます。あわせて公募の特集 号を組むことも検討してみたいと思っています。久しぶりの特集号です。みなさまの期待に添えるようなも のになればと思っております。

菊水 健史 